\title{
Transpositional reactivation of the Dart transposon family in rice lines derived from introgressive hybridization with Zizania latifolia
}

\author{
Ningning Wang ${ }^{1}$, Hongyan Wang ${ }^{1,2}$, Hui Wang ${ }^{1}$, Di Zhang ${ }^{1}$, Ying Wu' ${ }^{1}$ Xiufang Ou', Shuang Liu', Zhenying Dong ${ }^{1}$,
} Bao Liu ${ }^{1 *}$

\begin{abstract}
Background: It is widely recognized that interspecific hybridization may induce "genome shock", and lead to genetic and epigenetic instabilities in the resultant hybrids and/or backcrossed introgressants. A prominent component involved in the genome shock is reactivation of cryptic transposable elements (TEs) in the hybrid genome, which is often associated with alteration in the elements' epigenetic modifications like cytosine DNA methylation. We have previously reported that introgressants derived from hybridization between Oryza sativa (rice) and Zizania latifolia manifested substantial methylation re-patterning and rampant mobilization of two TEs, a copia retrotransposon Tos 17 and a MITE mPing. It was not known however whether other types of TEs had also been transpositionally reactivated in these introgressants, their relevance to alteration in cytosine methylation, and their impact on expression of adjacent cellular genes.
\end{abstract}

Results: We document in this study that the Dart TE family was transpositionally reactivated followed by stabilization in all three studied introgressants (RZ1, RZ2 and RZ35) derived from introgressive hybridization between rice (cv. Matsumae) and Z. latifolia, while the TEs remained quiescent in the recipient rice genome. Transposon-display (TD) and sequencing verified the element's mobility and mapped the excisions and reinsertions to the rice chromosomes. Methylation-sensitive Southern blotting showed that the Dart TEs were heavily methylated along their entire length, and moderate alteration in cytosine methylation patterns occurred in the introgressants relative to their rice parental line. Real-time qRT-PCR quantification on the relative transcript abundance of six single-copy genes flanking the newly excised or inserted Dart-related TE copies indicated that whereas marked difference in the expression of all four genes in both tissues (leaf and root) were detected between the introgressants and their rice parental line under both normal and various stress conditions, the difference showed little association with the presence or absence of the newly mobilized Dart-related TEs.

Conclusion: Introgressive hybridization has induced transpositional reactivation of the otherwise immobile Dartrelated TEs in the parental rice line (cv. Matsumae), which was accompanied with a moderate alteration in the element's cytosine methylation. Significant difference in expression of the Dart-adjacent genes occurred between the introgressants and their rice parental line under both normal and various abiotic stress conditions, but the alteration in gene expression was not coupled with the TEs.

\section{Background}

It is widely recognized that hybridization between genetically differentiated natural plant populations may cause structural genomic changes (e.g., via homoeologous or

\footnotetext{
* Correspondence: baoliu@nenu.edu.cn

'Key Laboratory of Molecular Epigenetics of MOE and Institute of Genetics \& Cytology, Northeast Normal University, Changchun 130024, China Full list of author information is available at the end of the article
}

ectopic recombination) as well as perturbation of epigenetic state of the recipient genome (e.g., DNA methylation), and both may result in heritable phenotypic novelties [1-7]. These findings are consistent with Barbara McClintock's insight of "genome shock", which proposed that crossing of different organismal species may cause restructuring of the resultant hybrid genome, and which may represent a facet of adaptive response by

\section{C) Biomed Central}


plants under specific circumstances [8]. A major cause underlying the genomic shock symptom is transcriptional and transpositional reactivation of otherwise cryptic transposable elements (TEs) in the hybrid genome. The reactivation of TEs is often coupled with disruption of chromatin-based epigenetic controlling mechanisms in the hybrid genome, like loss or re-patterning of cytosine methylation and compromised targeting by small interference (si) RNAs [9-11]. Indeed, several studies in both animals and plants have provided compelling empirical evidence in support of the "TE-epigenetic" basis of genome shock [12-16].

At least circumstantial evidence has indicated that for the hybridization- associated genomic shock to occur, a symmetric hybrid genome is not a prerequisite; instead, introgression or integration of "foreign" chromatin or DNA segments via introgressive hybridization or other means (e.g., transgenic) might as well produce the "shocking" effects on the recipient genome [11]. For example, it was shown in cultured animal cells that random integration of pieces of foreign DNA can cause the host genome to undergo extensive and genome-wide alterations in cytosine methylation of both cellular genes and TE-related DNA repeats $[17,18]$. We have demonstrated that introgression of small amount of chromatin of Zizania latifolia (a distantly related species to Oryza) into rice has caused an array of genetic and epigenetic instabilities in the recipient rice genome $[19,20]$, and in particular, rampant mobilization of a copia retrotransposon Tos17 and a MITE (mPing) [21]. Given the recent finding that the cellular controlling mechanisms for TE activity are likely individualized [22], it is interesting to explore whether TE reactivation in the rice-Zizania introgressants was confined to these two elements or other TEs also experienced reactivation.

The rice Dart transposon family belongs to the $h A T$ superfamily of class II TEs, and which was first characterized by Fujino and colleagues [23]. Dart was found as transcriptionally active in several rice tissues [24]. Moreover, both Dart and its deletion-derivative called $n$ Dart can be transpositionally active in certain rice genotypes that harbour active Dart, even under normal growing conditions [25]. In addition, the element's activity was correlated with its cytosine methylation state, and epigenetically silenced Dart copies can be reactivated by 5 azacytidine treatment [25,26]. Apparently, except for Tos17 and mPing, the Dart/nDart represents another family of highly active TEs endogenous to the rice genome.

The aim of this study was to investigate (1) whether the Dart TE family was transpositionally reactivated in the same set of rice-Zizania introgressants that showed rampant mobilization of Tos 17 and mPing [21]; (2) whether the element's activity was correlated with its cytosine methylation state; and (3) whether excision and reinsertion of the element copies impacted expression of their adjacent genes under normal or various abiotic stress conditions.

\section{Results}

The Dart transposon family was transpositionally reactivated in the rice-Zizania introgressants

Based on the sequence of a full-length copy of Dart1 [23], we used the same pair of primers that should be specific to all conserved Dart-related elements to amplify a 296 bp fragment within the ORF region, designed by Fujino et al. [23]. The fragment was verified by sequencing, and then used as a probe for Southern blotting on HindIII-digested genomic DNAs of the three representative introgressants of rice-Zizania (RZ1, RZ2 and RZ35) together with their recipient rice parental line (Matsumae) and the donor species $Z$. latifolia. Since there are only two restriction site of HindIII within the full-length Dart (Figure 1a), Southern blotting with this enzyme-digest and a probe residing on one side of both of the restriction sites should enable a conservative estimation on the copy number of all conserved Dart-related elements and their possible transpositions or rearrangements. Because in certain rice genotypes that harbour intrinsically active Dart copies, the elements can be spontaneously transposing even under normal growing conditions [25], it was important to determine whether this was the case for cultivar Matsumae, the rice parental line for the introgressants. We thus first tested this possibility in 24 randomly selected individuals of three successive selfed-generations of Matsumae, and subjected the plants to the Southern blot analysis probed by the Dart-specific fragment. We found a uniform hybridization pattern for all the 24 plants (Figure 1b), indicating that Matsumae, as in most rice cultivars [23], did not contain an active Dart. In contrast, each of the three introgressants showed a dramatically changed hybridization pattern, and all were substantially different from that of their rice parental line Matsumae (Figure 1c). Because the donor species, $Z$. latifolia, did not contain a homologue of Dart-related element (no hybridization signal), the Southern blotting results suggest that most of the Dart copies were likely transpositionally reactivated in the rice-Zizania introgressants, and produced an array of excisions and reinsertions in the introgressants (Figure 1). Nonetheless, it should be noted that an alternative explanation that the changed hybridization patterns in the introgressants resulted from genomic rearrangements involving the Dart-related TEs could not be ruled out at this stage solely based on the Southern blot analysis.

To distinguish the two possibilities between transposition and rearrangement as a cause for the changed 


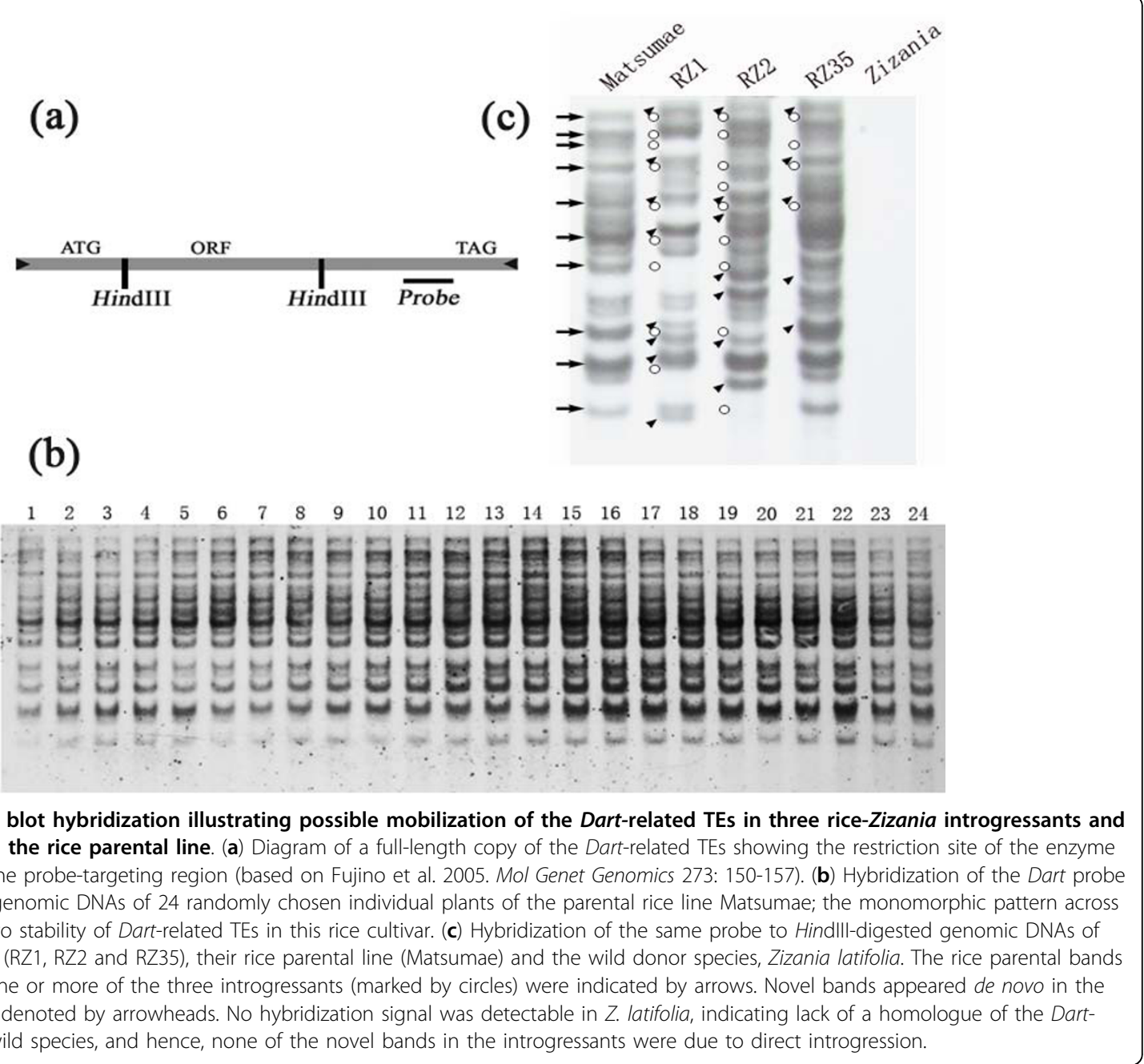

Southern blotting patterns of Dart-related TEs in the rice-Zizania introgressants, we resorted to the Dart-specific transposon-display (TD) developed by Tsugan et al. (2006) [25] to isolate possible excision and reinsertion events that likely had occurred in the introgressants relative to their rice parental line. The results of the TD profiles showed that both the patterns and total numbers of amplified bands were very similar between the iDart1-51/nDart1-3 and iDart1s/nDart1-101s subgroups with the primer pairs used, indicating they were mainly targeting to overlapping genomic regions (e.g., Figure 2a). An unexpected observation was that many bands were also amplified from the donor species, $Z$. latifolia (e.g., Figure 2a). Because there was no homologue for the Dart-related TEs in the Zizania genome both based on the Southern blotting results (Figure 1c) and on the Dart-specific PCR amplification using Z. latifolia genomic DNA as a template (data not shown), we suspect that these bands were not resulted from TD, but from the homo-amplification by the MseI-adaptor primers in the silver-stained profiles, in which all amplicons were visible (in contrast to radioactively albelled primers). To test this, we sequenced 17 bands isolated from the $Z$. latifolia lanes; mainly those bands the positions of which were either identical or proximal to bands existing in the introgressant(s) but not in the rice parent were selected to maximize the likelihood of detecting possible Zizania introgression. We found that all the sequenced bands contained the same MseI-adaptor primer at both ends, and none contained the terminus of Dart-related TE that should be expected for a bona fide TD band. This suggested that (1) the novel bands in the introgressant(s) were not likely due to direct introgression from the donor species, Z. latifolia; (2) there was probably no homologue of Dart-related TEs in Z. latifolia, consistent with the Southern blotting and Dart-specific PCR amplification results (Figure 1c). The tabulated Dart-TD results by the 18 primer pairs (see Additional file 1) enabled an gross estimate of the putative excision (loss of rice parental bands) and reinsertion 


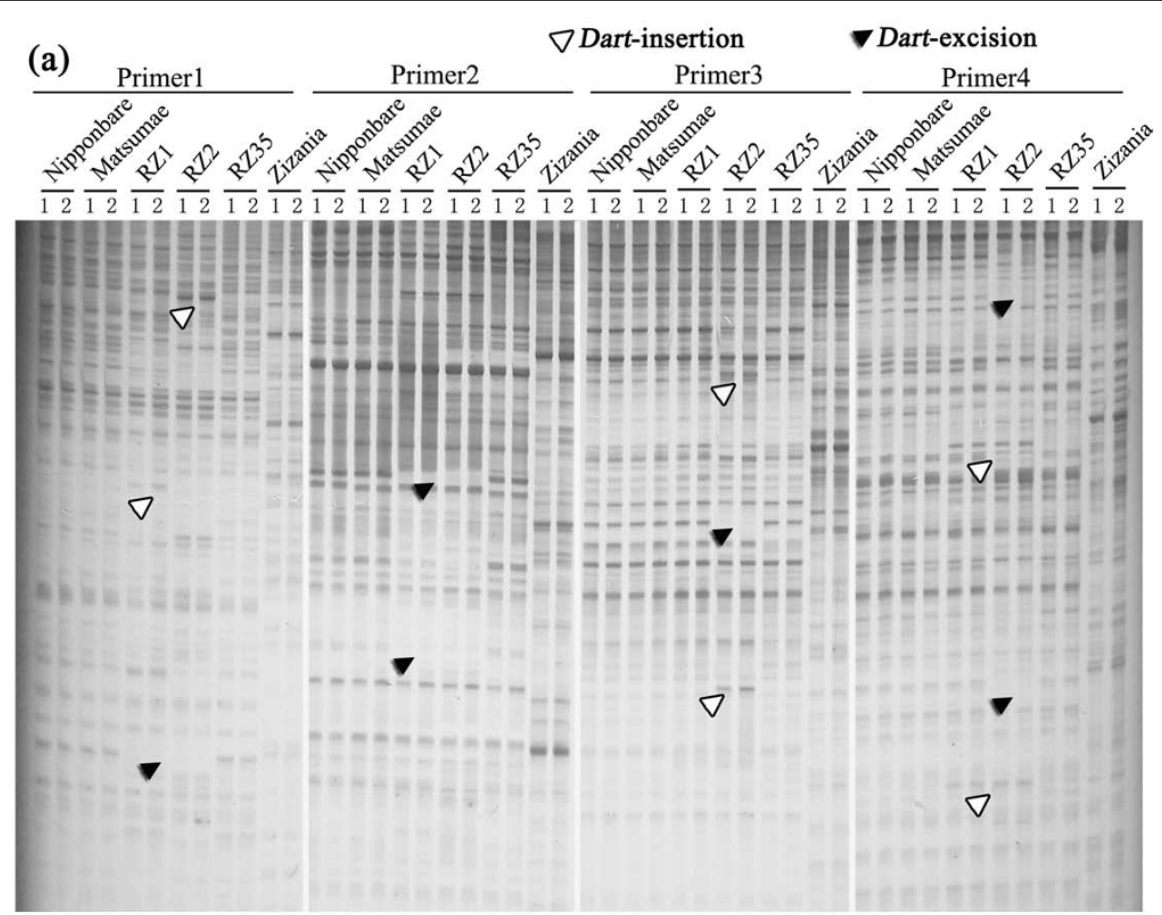

(b)

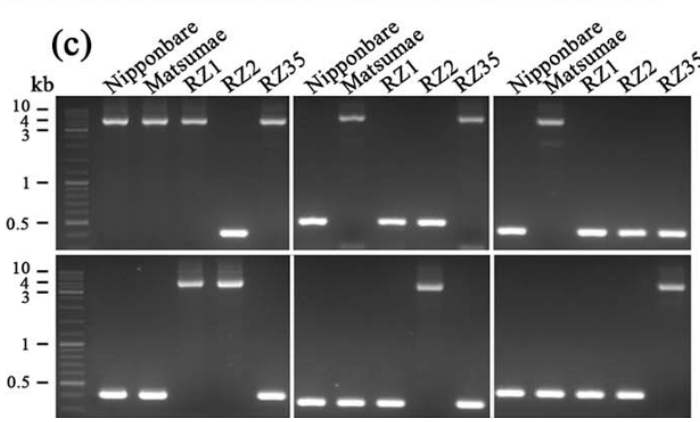

Figure 2 Mobilization of the Dart-related TEs in three rice-Zizania introgressants revealed by transposon-display (TD) and validated by locus-specific PCR amplification. (a) Exemplary profiles of Dart-specific TD. (b) Tabulated frequencies of excision and reinsertion of the element in each of the introgressants based on the TD-data. (c) Validation of the element transpositional activity by locus-specific PCR amplifications. The black and while triangles labelled in (a) denote excisions and reinsertions, respectively. Lanes 1 and 2 in (a) and (c) refer to TDs with the iDart151/nDart1-3 and iDart1s/nDart1-101s subgroup-specific primers (detailed in the manuscript text). The upper panel in (c) (from left to right) are examples of Dart-excisions that occurred in one (RZ2), two (RZ1 and RZ2) and all three (RZ1, RZ2 and RZ35) introgressants, which were detected with primers Dart-TDE-5, Dart-TDE-2 and Dart-TDE-3, respectively; the lower panel in (c) (from left to right) are examples of Dart-reinsertions that occurred in two (RZ1 and RZ2), one (RZ2) and one (RZ35) of the introgressants, respectively, which were detected with primers Dart-TDI-7, DartTDI-1 and Dart-TDI-27, respectively. Note that for a given locus, the fully sequenced standard rice cultivar Nipponbare, based on which the locusspecific primers were designed, may or may not contain the Dart copy.

(gain of novel bands) frequencies of $9 \%$ and $24 \%$ for RZ1, $26 \%$ and $35 \%$ for RZ2, and $1 \%$ and $5 \%$ for RZ35, respectively (Figure $2 \mathrm{~b}$ ). These results indicated that, first, more insertions than excisions had occurred in all three introgressants; second, there was marked difference in the transpositional activity of the Dart-related TEs among the three introgressants, with RZ2 showed the most and RZ35 the least activities.

Next, we cloned and sequenced a subset of 60 bands, each of which was variable in one or more of the introgressants relative to the corresponding position in the rice parental line (Matsumae) in the TD profiles. These variant bands included 30 putative excisions (present in Matsumae but absent from at least one of the introgressants) and 30 putative insertions (appeared de novo in one or more of the introgressants). We found that for each of the clones sequenced, the expected terminus encompassing the 19-bp terminal inverted repeat (TIR) of Dart was identified, indicating that these isolated bands were 
Table 1 Excision sites of Dart-related TEs identified by transposons-display (TD) (designated as Dart-TDE) in the riceZizania introgressants

\begin{tabular}{|c|c|c|c|c|}
\hline Excision sites & Excision position $^{\S}$ & Locus-specific primers $\left(5^{\prime}-3^{\prime}\right)$ & Excised from & Excision flanks \\
\hline Dart-TDE-1 & $\begin{array}{l}\text { Chr.2 } \\
\text { Position:11650578 } \\
\text { Non-coding }\end{array}$ & $\begin{array}{l}\text { For: tgcgcacaatcacctctatg } \\
\text { Rev: cttgtggtgcaaccaaccta }\end{array}$ & $\begin{array}{l}\text { RZ1, } \\
\text { RZ2 }\end{array}$ & $\begin{array}{l}\text { acaatcacctctatg }<\text { Dart }>\text { aatgcacacactcat } \\
\text { acaatcacctctatg_- }\end{array}$ \\
\hline Dart-TDE-2 & $\begin{array}{l}\text { Chr.4 } \\
\text { Position: } 2633169 \\
\text { Non-coding }\end{array}$ & $\begin{array}{l}\text { For: gtgcgcgtaatgctagaaaa } \\
\text { Rev: cagggagggagggattagag }\end{array}$ & $R Z 1, R Z 2$ & $\begin{array}{l}\text { acaatcacctctatg }<\text { Dart }>\text { aatgcacacactcat } \\
\text { acaatcacctctatg_- _ _ - aatgcacacactcat }\end{array}$ \\
\hline Dart-TDE-3 & $\begin{array}{l}\text { Chr.7 } \\
\text { Position: } 20137929 \\
\text { Non-coding }\end{array}$ & $\begin{array}{l}\text { For: cccccatacttaccgcatta } \\
\text { Rev: cctaggtgttctgccgactc }\end{array}$ & $\begin{array}{l}\text { RZ1, } \\
\text { RZ2, } \\
\text { RZ35 }\end{array}$ & $\begin{array}{l}\text { ttgtaaattaactcc }<\text { Dart }>\text { aaaccatctcctatc } \\
\text { ttgtaaattaactcc - — ——_ aaaccatctcctatc }\end{array}$ \\
\hline Dart-TDE-5 & $\begin{array}{l}\text { Chr.11 } \\
\text { Position:16475838 } \\
\text { Non-coding }\end{array}$ & $\begin{array}{l}\text { For: tgagtgacgtgaagccaaag } \\
\text { Rev: acagatcacggcagggttac }\end{array}$ & RZ2 & $\begin{array}{l}\text { aggtcggttaagcct< }<\text { Dart }>\text { aagaaccacgaataa } \\
\text { aggtcggttaagcct-———aagaaccacgaataa }\end{array}$ \\
\hline Dart-TDE-7 & $\begin{array}{l}\text { Chr.4 } \\
\text { Position:18387453 } \\
\text { Non-coding }\end{array}$ & $\begin{array}{l}\text { For: cctctaggcacctccctttt } \\
\text { Rev: caggagcaacaattgcatgt }\end{array}$ & RZ2 & $\begin{array}{l}\text { ctccctttttttta }<\text { Dart }>\text { gaactaatgactttt } \\
\text { ctcccttttttaa gaactaatgactttt }\end{array}$ \\
\hline Dart-TDE-8 & $\begin{array}{l}\text { Chr.1 } \\
\text { Position:18893612 } \\
\text { Non-coding }\end{array}$ & $\begin{array}{l}\text { For: tggtttggaggtcggttaag } \\
\text { Rev: cacatgtcagccaaaaccac }\end{array}$ & RZ2 & $\begin{array}{l}\text { catcagattaagaaa }<\text { Dart }>\text { tccggtgaaaccatc } \\
\text { catcagattaagaaa_- }\end{array}$ \\
\hline Dart-TDE-10 & $\begin{array}{l}\text { Chr.11 } \\
\text { Position:22507932 } \\
\text { Non-coding }\end{array}$ & $\begin{array}{l}\text { For: gagaagagcacgggaagttg } \\
\text { Rev: aactggctgttcgctcaagt }\end{array}$ & $\mathrm{RZ2}$ & $\begin{array}{l}\text { taccgcattaaccac }<\text { Dart }>\text { ttaggtaggatacat } \\
\text { taccgcattaaccac }-1-1 t a g g t a g g a t a c a t\end{array}$ \\
\hline Dart-TDE-11 & $\begin{array}{l}\text { Chr.8 } \\
\text { Position: } 15326441 \\
\text { Non-coding }\end{array}$ & $\begin{array}{l}\text { For: tcgtgttcccaaattcacac } \\
\text { Rev: catatatcccgcagaaaagca }\end{array}$ & $R Z 1, R Z 2$ & $\begin{array}{l}\text { cctccacctctaca }<\text { Dart }>\text { aaaatttctactgttc } \\
\text { cctccacctctaca- — ——-aaaatttctactgttc }\end{array}$ \\
\hline Dart-TDE-15 & $\begin{array}{l}\text { Chr.3 } \\
\text { Position: } 20176647 \\
\text { Non-coding }\end{array}$ & $\begin{array}{l}\text { For: aacgagagcaagggagatgaa } \\
\text { Rev: ttaagccagggcaagtacacg }\end{array}$ & RZ2 & $\begin{array}{l}\text { tcctacgtcactg }<\text { Dart }>\text { ttgagg cgagccaaa } \\
\text { tcctacgtcactg- - - - ttgaggcgagccaaa }\end{array}$ \\
\hline Dart-TDE-16 & $\begin{array}{l}\text { Chr.9 } \\
\text { Position: } 21368076 \\
\text { Non-coding }\end{array}$ & $\begin{array}{l}\text { For: gtgcatggatttgaccttta } \\
\text { Rev: ctgtgctcacttcgctactacta }\end{array}$ & RZ1 & $\begin{array}{l}\text { atattgccatttaa }<\text { Dart }>\text { gtgtcatcgectta } \\
\text { atattgccatttaa_- - gtgtcatcgcctta }\end{array}$ \\
\hline Dart-TDE-19 & $\begin{array}{l}\text { Chr.10 } \\
\text { Position: } 7832680 \\
\text { Non-coding }\end{array}$ & $\begin{array}{l}\text { For: ggtgtaacgattgctaaggcg } \\
\text { Rev: agtggggggagagtaagatga }\end{array}$ & $R Z 2$ & $\begin{array}{l}\text { tctttttttacgca }<\text { Dart }>\text { tgcagaggtgacg } \\
\text { tctttttttacgca }<\text { Dart }>\text { tgcagaggtgacg }\end{array}$ \\
\hline Dart-TDE-20 & $\begin{array}{l}\text { Chr.11 } \\
\text { Position: } 7910449 \\
\text { Os11g0247800 exon }\end{array}$ & $\begin{array}{l}\text { For: agagttcttgccaaccatgc } \\
\text { Rev: ggaagagggaaaaaccaagc }\end{array}$ & $R Z 1, R Z 2$ & $\begin{array}{l}\text { tctaatacctctag }<\text { Dart }>\text { gactgctttccacatg } \\
\text { Tctaatacctctag- - - - gactgctttccacatg }\end{array}$ \\
\hline Dart-TDE-21 & $\begin{array}{l}\text { Chr.7 } \\
\text { Position: } 16720991 \\
\text { Non-coding }\end{array}$ & $\begin{array}{l}\text { For: cgatcgagaatttccgagac } \\
\text { Rev: tggtctgttcgttgtccaaa }\end{array}$ & RZ1 & $\begin{array}{l}\text { tttcaccccctatat }<\text { Dart }>\text { tggtaccatcaattt } \\
\text { Tttcaccccctatat_- _ — - tggtaccatcaattt }\end{array}$ \\
\hline Dart-TDE-23 & $\begin{array}{l}\text { Chr.6 } \\
\text { Position: } 6273602 \\
\text { Non-coding }\end{array}$ & $\begin{array}{l}\text { For: cttttgggctgtgatggagt } \\
\text { Rev: ttaaggacgatgccaaaacc }\end{array}$ & RZ2 & $\begin{array}{l}\text { ttctgtccaccccta }<\text { Dart }>\text { gctggtatttatat } \\
\text { ttctgtccaccccta- - - gctggtatttatat }\end{array}$ \\
\hline Dart-TDE-25 & $\begin{array}{l}\text { Chr.6 } \\
\text { Position: } 26631010 \\
\text { Non-coding }\end{array}$ & $\begin{array}{l}\text { For: cctcggtttccattagca } \\
\text { Rev: gtacggcctggcaagtga }\end{array}$ & $R Z 1, R Z 2$ & $\begin{array}{l}\text { tttgtccaccccta }<\text { Dart }>\text { tctactcctagttgc } \\
\text { Ttttgtccaccccta_- - - tctactcctagttgc }\end{array}$ \\
\hline
\end{tabular}

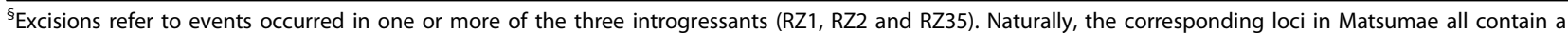
copy of Dart-related TE, whereas in Nipponbare only some of the loci contain the element, pointing to genotypic polymorphism with regard to presence/absence of the Dart-related TEs for a given genomic locus.

resulting from real TD rather than from homo-amplification by the adaptor primers. Further sequence analysis identified 15 and 21 of the variant TD bands as most likely resulted from excision and insertion events, respectively, because these bands contained the typical 8-bp target-site duplication (TSD) of Dart (Tables 1 and 2). Nonetheless, their authenticity as bona fide excisions and insertions rather than rearrangements entails further validation, as detailed below.
Validation and chromosomal location of the Dart excisions and insertions by locus-specific PCR amplification and sequencing in the rice-Zizania introgressants

For each of the putative excised and inserted loci, we designed locus-specific primer pairs specific to the flanks of the Dart elements based on the whole genome sequence of Nipponbare http://rgp.dna.affrc.go.jp (Tables 1 and 2). Note that the design of primers 
Table 2 De novo insertion sites of Dart-related TEs identified by transposons-display (TD) (designated as Dart-TDI) in the rice-Zizania introgressants

\begin{tabular}{|c|c|c|c|c|c|}
\hline Insertion sites & Position of insertion sites & Locus-specific primers $\left(5^{\prime}-3^{\prime}\right)$ & Inserted into & $\operatorname{TIR}\left(5^{\prime}-3^{\prime}\right)$ & $\operatorname{TSD}\left(5^{\prime}-3^{\prime}\right)$ \\
\hline Dart-TDI-1 & $\begin{array}{l}\text { Chr.3; position: 2726981; } \\
\text { non-coding }\end{array}$ & $\begin{array}{l}\text { For: tcacgcagtagatgccaaag } \\
\text { Rev: gcacgtctccgtagctctct }\end{array}$ & RZ2 & gcccatttggccacctcta & tgctagta \\
\hline Dart-TDI-3 & $\begin{array}{l}\text { Chr.10; position:4241777; } \\
\text { OSJNAb0015J03.2 exon }\end{array}$ & $\begin{array}{l}\text { For: gtagagggctcaatcgtgga } \\
\text { Rev: ctaaggtctcgaggcacacc }\end{array}$ & $\begin{array}{l}\text { RZ1, } \\
\text { RZ2 }\end{array}$ & geccatttggecacctcta & gcatgaag \\
\hline Dart-TDI-4 & $\begin{array}{l}\text { Chr.5; position: 29238540; } \\
\text { non-coding }\end{array}$ & $\begin{array}{l}\text { For: gcccgtttggccacctctat } \\
\text { Rev: tgtaaaatgaccagcgacga }\end{array}$ & $\begin{array}{l}\text { RZ1, } \\
\text { RZ2, RZ35 }\end{array}$ & geccatttggecacctcta & tgtggttg \\
\hline Dart-TDI-5 & $\begin{array}{l}\text { Chr.5; position:14917879; } \\
\text { non-coding }\end{array}$ & $\begin{array}{l}\text { For: tacggttcccattgttttcc } \\
\text { Rev: gggtgtgcacgatgttgtaa }\end{array}$ & RZ2 & gcccatttggecacctcta & tacaatgt \\
\hline Dart-TDI-7 & $\begin{array}{l}\text { Chr.12; position:12726861; } \\
\text { non-coding }\end{array}$ & $\begin{array}{l}\text { For: ttgttgttagttttgcgtgtaga } \\
\text { Rev: gaaagcaggttggagaggtta }\end{array}$ & $\begin{array}{l}\text { RZ1, } \\
\text { RZ2 }\end{array}$ & gcccatttggecacctcta & cgctagta \\
\hline Dart-TDI-8 & $\begin{array}{l}\text { Chr.3; position:27833204; } \\
\text { Os03g0699200 exon }\end{array}$ & $\begin{array}{l}\text { For: taattaagttggaagtgggaca } \\
\text { Rev: tttctgtaagattacaaccagaggt }\end{array}$ & $\begin{array}{l}\text { RZ1, } \\
\text { RZ2, RZ35 }\end{array}$ & geccatttggecacctcta & tggagtat \\
\hline Dart-TDI-10 & $\begin{array}{l}\text { Chr.3; position:17730615; } \\
\text { non-coding }\end{array}$ & $\begin{array}{l}\text { For: ctttcgtaggcgaaaagtgc } \\
\text { Rev: ctgcaaccacctgtctctga }\end{array}$ & RZ2 & gcccatttggecacctcta & cgaagaac \\
\hline Dart-TDI-11 & $\begin{array}{l}\text { Chr.4; position:638561; } \\
\text { non-coding }\end{array}$ & $\begin{array}{l}\text { For: catgaattgggtgccatgta } \\
\text { Rev: ccccatagggtaggcaaaat }\end{array}$ & $\begin{array}{l}\text { RZ1, } \\
\text { RZ2, RZ35 }\end{array}$ & geccatttggecacctcta & tctgaatt \\
\hline Dart-TDI-16 & $\begin{array}{l}\text { Chr.5; position:10010289; } \\
\text { non-coding }\end{array}$ & $\begin{array}{l}\text { For: gcccgtttggecacctctat } \\
\text { Rev: ggtggaggacctgctcaata }\end{array}$ & $\begin{array}{l}\text { RZ1, } \\
\text { RZ2 }\end{array}$ & gcccatttggecacctcta & ttcgacat \\
\hline Dart-TDI-18 & $\begin{array}{l}\text { Chr.12; position:6156546; } \\
\text { non-coding }\end{array}$ & $\begin{array}{l}\text { For: tgagcacgcctagctcagta } \\
\text { Rev: atgcacggcaactttctctt }\end{array}$ & $\begin{array}{l}\text { RZ1, } \\
\text { RZ2 }\end{array}$ & gcccatttggecacctcta & cctctcaa \\
\hline Dart-TDI-19 & $\begin{array}{l}\text { Chr.12; position:6345593; } \\
\text { non-coding }\end{array}$ & $\begin{array}{l}\text { For: gcccgtttggecacctctac } \\
\text { Rev: acaaatggectcctgtgttc }\end{array}$ & RZ1 & gcccatttggecacctcta & caagcagc \\
\hline Dart-TDI-20 & $\begin{array}{l}\text { Chr.12; position:21951729; } \\
\text { non-coding }\end{array}$ & $\begin{array}{l}\text { For: tccagccaaaccctgttc } \\
\text { Rev: gctcgccagatgtcaggt }\end{array}$ & RZ1 & gcccatttggecacctcta & cgtcggga \\
\hline Dart-TDI-21 & $\begin{array}{l}\text { Chr.1; position:19308190; } \\
\text { non-coding }\end{array}$ & $\begin{array}{l}\text { For: tgctacagtagaagggcgtgta } \\
\text { Rev: atgcacatctggtcttttgatg }\end{array}$ & RZ2 & gcccatttggecacctcta & cacacgta \\
\hline Dart-TDI-22 & $\begin{array}{l}\text { Chr.2; position:6211564; } \\
\text { non-coding }\end{array}$ & $\begin{array}{l}\text { For: ggatccgtttggatcagaga } \\
\text { Rev: tgcagcagctgattcatacc }\end{array}$ & RZ2 & gcccatttggecacctcta & ccaatatt \\
\hline Dart-TDI-24 & $\begin{array}{l}\text { Chr.5; position:10749306; } \\
\text { OSJNBa0037H03.12 intro }\end{array}$ & $\begin{array}{l}\text { For: gagctgctcctgaaaaccac } \\
\text { Rev: gaattttccttgccgtgtgt }\end{array}$ & $\begin{array}{l}\text { RZ1, } \\
\text { RZ2 }\end{array}$ & gcccatttggecacctcta & tcatgttt \\
\hline Dart-TDI-25 & $\begin{array}{l}\text { Chr.1; position:25299; } \\
\text { non-coding }\end{array}$ & $\begin{array}{l}\text { For: gtgccggagaatgatttgat } \\
\text { Rev: atttccctcgatgcactgtc }\end{array}$ & $\begin{array}{l}\text { RZ1, } \\
\text { RZ2 }\end{array}$ & geccatttggecacctcta & tacgcagc \\
\hline Dart-TDI-26 & $\begin{array}{l}\text { Chr.2; position:10207338; } \\
\text { Os02g0277600 intro }\end{array}$ & $\begin{array}{l}\text { For: gcccatttggccacctcta } \\
\text { Rev: cgaatgagtgtccttgatcg }\end{array}$ & $\begin{array}{l}\text { RZ1, } \\
\text { RZ2 }\end{array}$ & gcccatttggecacctcta & agcaaaac \\
\hline Dart-TDI-27 & $\begin{array}{l}\text { Chr.12; position:23594158; } \\
\text { Os12g0572000 3'UTR }\end{array}$ & $\begin{array}{l}\text { For: gcccgtttggccacctctac } \\
\text { Rev: agcaacccacagaacagctt }\end{array}$ & RZ35 & geccatttggecacctcta & ccaccctc \\
\hline Dart-TDI-28 & $\begin{array}{l}\text { Chr.8; position:23713525; } \\
\text { non-coding }\end{array}$ & $\begin{array}{l}\text { For: gcccgtttggccacctctac } \\
\text { Rev: tctgcggttgaaacaatgag }\end{array}$ & RZ2 & gcccatttggecacctcta & cggctaac \\
\hline Dart-TDI-29 & $\begin{array}{l}\text { Chr.7; position:20028374; } \\
\text { non-coding }\end{array}$ & $\begin{array}{l}\text { For: gcccgtttggccacctctat } \\
\text { Rev: aaagtcaatggaaaggggaaa }\end{array}$ & $\begin{array}{l}\text { RZ1, } \\
\text { RZ2 }\end{array}$ & gcccatttggecacctcta & tcaaaatc \\
\hline Dart-TDI-30 & $\begin{array}{l}\text { Chr.4; position:25704503; } \\
\text { Os04g0514800 exon }\end{array}$ & $\begin{array}{l}\text { For: gcccatttggccacctcta } \\
\text { Rev: ggcaatgcggttggtttc }\end{array}$ & $\begin{array}{l}\mathrm{RZ1} \\
\mathrm{RZ2}\end{array}$ & geccatttggecacctcta & cgctattc \\
\hline
\end{tabular}

targeting the flanks did not entail that Nipponbare contains a copy of the Dart-related TE at each of the loci. PCR amplification by these locus-specific primers (e.g., Figure 2c) and sequencing of the amplicons verified that all the 15 excisions and 21 insertions were authentic, because the immediate contiguous flanks were intact for all the excisions and typical TSDs were identified for all the insertions (Tables 1 and 2). This locus-specific PCR amplification and sequencing results thus validated transpositional reactivation of the Dart-related elements in the rice-Zizania introgressants.
We mapped all the 15 excisions and 21 insertions of Dart that occurred in the introgressants by aligning the identified flanking regions of each of the events against the whole genome sequence of Nipponbare. We found that the mobilized Dart-related elements mapped throughout the rice genome involving all the 12 chromosomes (Figure 3 ), suggesting that these seemingly random excisions and insertions by the Dart-related elements probably had not imposed an adverse effect on fitness of the introgressants, and hence, being selected for or neutrally retained during propagation of the plants via self-fertilization. 

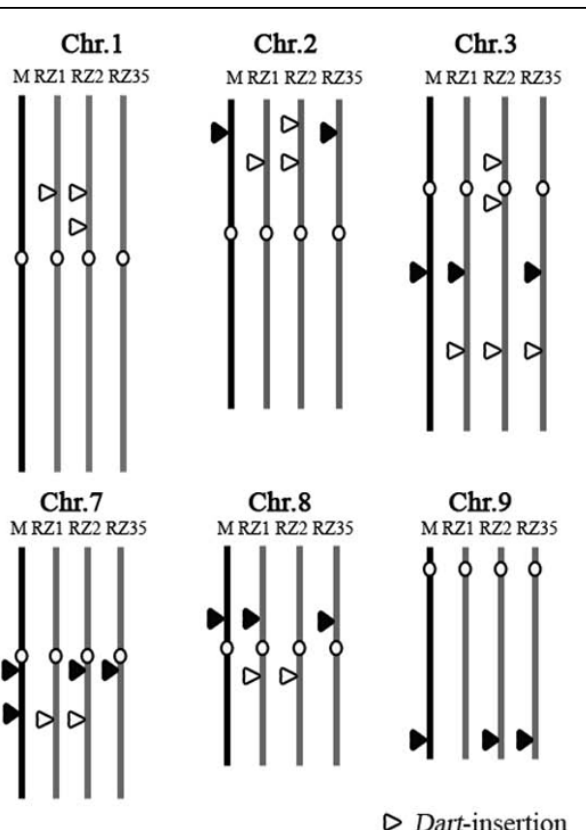

$\triangleright$ Dart-insertion
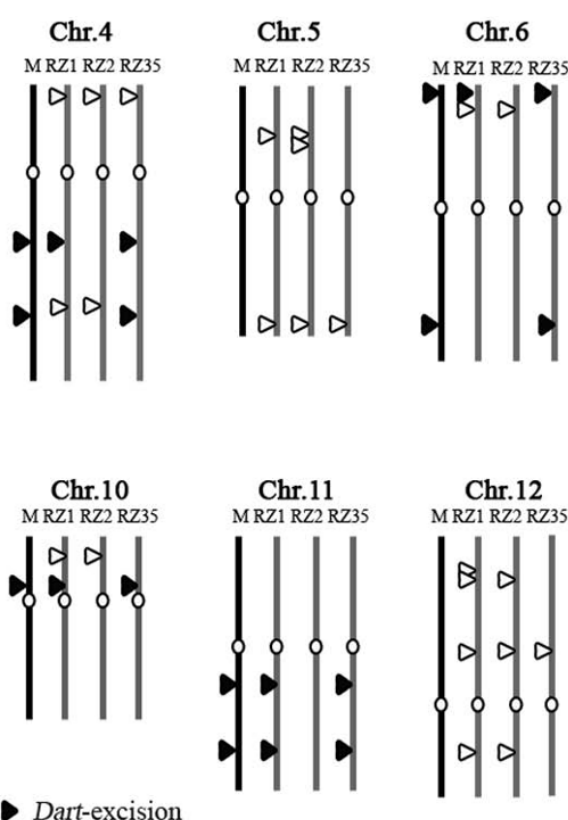

Figure 3 Electronic mapping of the excisions and insertions of the Dart-related TEs in three rice-Zizania introgressants based on the whole-genome sequence of the standard rice cultivar Nipponbare http://rgp.dna.affrc.go.jp. M denotes the rice parental line Matusumae. Excisions from the paretnal line and de novo insersions into the introgressant(s) were labelled.

\section{Cytosine methylation states of the Dart-related elements} in the rice-Zizania introgressants and their rice

\section{parental line}

Given our previous results that cytosine methylation of these rice-Zizania introgressants were substantially repatterned relative to their rice parental line Matsumae [19], and the established frequent causal links between TE activity and its methylation state by numerous studies $[9,10,22,24,27-30]$, it was interesting to test whether the transposition of Dart in the introgressants was accompanied with alteration in this epigenetic marker. Thus, we investigated the methylation state of the Dartrelated elements in the introgressants $v s$. that in Matsumae. We first delineated the Dart-related elements by digestion with $B a m \mathrm{HI}$, which had two restriction sites within Dart1 (and by extension all conserved copies of Dart-related TEs) at positions $678 \mathrm{nt}$ and $2910 \mathrm{nt}$, respectively, and hence, in theory digestion with this enzyme would produce three fragments for each of the conserved Dart copies: the delineated internal bodyregion (2232 bp in length) and the 5'- and 3'-terminus together with their contiguous flanks (Figure 4a). We noted however that several major hybridization bands above the delineated 2232 bp body-region band were detected by the region-specific probe (Figure $4 \mathrm{~b}$, the body-region probe), indicating that either some of the Dart-related elements were not conserved at the BamHI restriction site(s), or there had been insertions by related or unrelated sequences within the two restriction sites, and hence producing larger-sized fragments after the enzyme restriction. Nonetheless, those Dart-related elements that gave rise to the $2232 \mathrm{bp}$ band were amenable to methylation analysis of the body-region, because there had been no apparent internal truncations, as detailed below.

We next performed the second round restriction by adding each of the pair of isoschizomers, HpaII and $M s p \mathrm{I}$, to the BamHI-digests, and using probes specific to each of the three regions to assess their cytosine methylation state in the introgressants relative to Matsumae. We obtained the following results: (1) there had been no detectable internal truncations between the two BamHI sites, as no clear, smaller-sized bands than the expected 2232 bp were detected in this enzyme digest (Figure 4b, the body-region probe); (2) the body-region of the conserved, Dart-related elements was heavily methylated particularly by ${ }^{\mathrm{m}} \mathrm{CG}$ in all the rice lines, introgressants and parental, as evidenced by the very similar hybridization patterns between BamHI-digest and BamHI+HapII-digest (Figure 4b, the body-region probe), albeit there were 11 5'-CCGG sites within this region of Dart-related elements, and hence several smaller-sized bands would have been detected if the relevant 5'-CCGG sites were hypomethylated (Figure 4a); (3) the only clear difference in the methylation state of the introgressants relative to Matsumae was that one introgressant (RZ35) showed hypermethylation as evidenced by the disappearance of several smaller-sized bands 


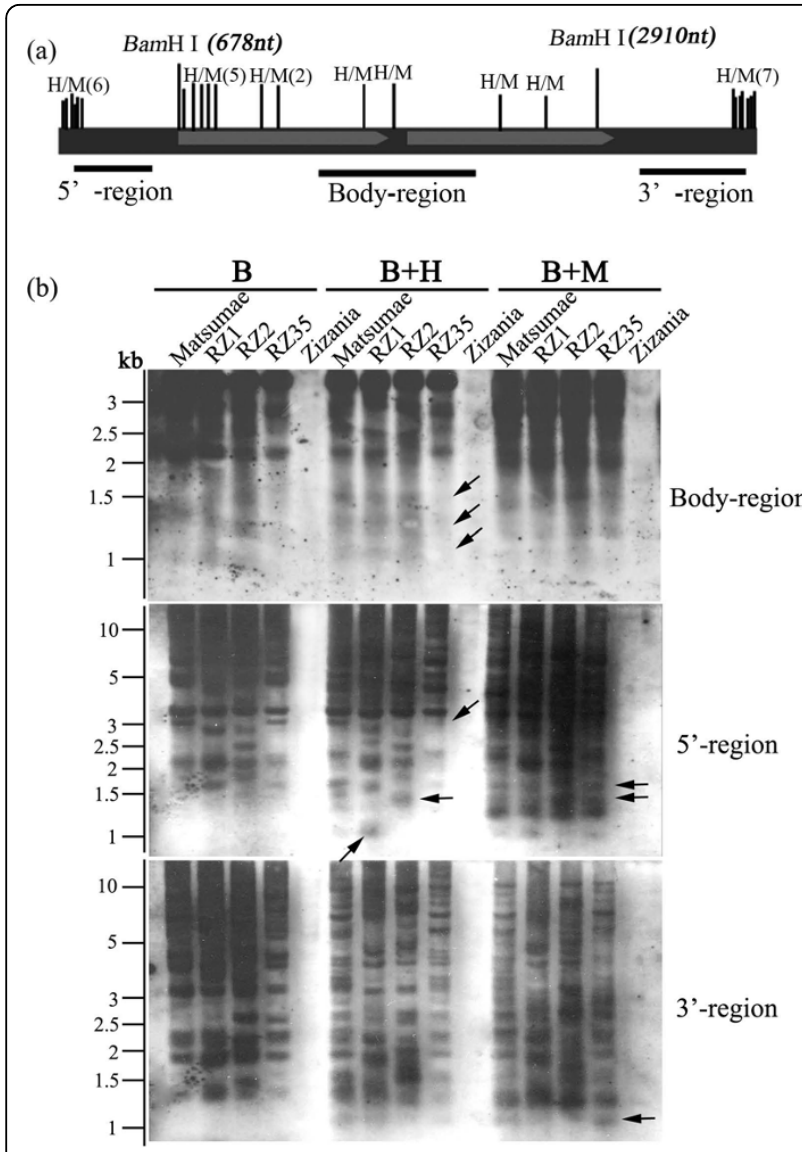

Figure 4 Alteration in cytosine methylation at the $5^{\prime}$-CCGG sites within and immediately flanking the Dart-related TEs in three rice-Zizania introgressants, detected by methylationsensitive Southern blot analysis. (a) Restriction maps of enzymes BamHI and Hpall/Mspl for Dart-related TEs. The restriction sites for the enzyme (BamHI) used to delineate Dart-related TEs and the pair of isoschizomers, Hpall/Mspl (H/M), within the elements are indicated. Fragments to be used as probes that are respectively specific to the 5'-, 3'- and body-regions are denoted by solid bars. (b) Hybridization of each of the three probes (uppermost: the bodyregion, middle: the $5^{\prime}$-region, lowermost: the 3 '-region) to a blot carrying single- or double-enzyme digested genomic DNA of the introgressants and their parental lines, rice (cv. Matsumae) and Z. latifolia. The enzymes used were indicated on the top of the blot: BamHI (B), Hpall (H) and Mspl (M). The altered bands indicative of methylation alterations in the introgressant(s) are arrowed.

(Figure 4b, the body-region probe; marked by arrows); (4) the 5' region of the Dart-related elements was also heavily methylated by both ${ }^{\mathrm{m}} \mathrm{CG}$ and ${ }^{\mathrm{m}} \mathrm{CNG}$ in the all the lines because multiple bands were detected (Figure $4 \mathrm{~b}$, the 5 ' probe), as otherwise we would have predominantly detected a band $<678$ bp in length (restricted by BamHI at position $678 \mathrm{nt}$ together with restriction by HpaII/MspI at one or more of the six 5'-CCGG sites at the 5'-terminus) (Figure 4a); (5) compared with Matsumae, CG demethylation in RZ1 and concomitant CG hypermethylation and CNG hypomethylation in RZ35 occurred in the 5'-region of Dart-related elements (Figure $4 \mathrm{~b}$, the 5 ' probe); (6) similar to the situation of 5'region, the 3'-region of the Dart-related elements was also heavily methylated by both ${ }^{\mathrm{m}} \mathrm{CG}$ and ${ }^{\mathrm{m}} \mathrm{CNG}$ in all the lines (Figure $4 \mathrm{~b}$, the 3' probe), as otherwise we would have predominantly detected a band $<656 \mathrm{bp}$ in length (being restricted at position $2910 \mathrm{nt}$ by $\mathrm{BamHI}$ together with one or more of the seven 5'-CCGG sites by HpaII/MspI at the 3'-terminus) (Figure 4a); (7) compared with Matsumae, CG demethylation in RZ2 and CNG demethylation in RZ35 occurred in the 3'-region of the Dart-related elements (Figure 4b, the 3' probe); (8) with regard to the methylation state of the 5' and 3' flanks of the Dart-related elements, it was deducible that they had a substantially lower methylation level relative to the Dart-related elements per se, as evidenced by the multiple small-sized bands detected by the Dart 5'- and 3'-region-specific probes (Figure 4b). Taken together the Southern blotting data of all three regionspecific probes, it can be concluded that (1) the Dartrelated TEs are heavily methylated throughout the entire length, but with their 5' and 3' flanks being relatively less methylated compared with the internal body-region, in all the rice lines studied; (2) to a moderate extent, methylation alteration including both hypo- and hypermethylation occurred in the introgressants relative to their rice parental line Matsumae.

\section{Limited impact by mobility of the Dart-related TEs on expression of their adjacent genes under normal and abiotic stress conditions}

The seemingly random distribution of the excisions and insertions of the Dart-related TEs in the introgressants (Figure 3) raised the question as to whether their mobility had imposed any effect on expression of their neighbouring genes. To address this question, it was important to identify genes residing at unique-copy regions (ruling out possible confounding effects) neighbouring the newly mobilized insertion/excision sites of the Dart-related TEs; in addition, because we were interested in possible regulatory alterations rather than changes in the nucleotide sequence of the genes, we needed to select genes that would show identical amplification between the introgressants and their rice parental line if genomic DNA was used as templates. We thus extracted $10 \mathrm{~kb}$ of flanking genomic sequences $(5 \mathrm{~kb}$ on each side of an excised or inserted Dart-related TE) from the whole genome sequence of Nipponbare and used them as queries for similarity search against the full-length cDNA database of rice http://cdna01.dna. affrc.go.jp/cDNA. We identified six genes meeting the criteria of unique-copy, encoding either known-function or hypothetical proteins, and identical amplification 
among all lines on genomic DNA templates (Figures 5a and $5 \mathrm{~b}$ ). Real-time qRT-PCR analysis was performed with primers specific to each of the six genes on cDNAs derived respectively from the leaf and root tissues from 21-day-old seedlings of the three introgressants and their rice parental line that were grown under normal growing conditions (Figure 5c). The results showed that all six genes exhibited significant difference in the transcript abundance in at least one tissue and one introgressant relative to Matsumae (Figure 5c). Specifically, (1) gene 1, to which a Dart copy being inserted $662 \mathrm{bp}$ downstream in one introgressant (RZ2), showed significant down- and up-regulation, respectively, in the root tissue of RZ1 and RZ2; (2) gene 2, to which a Dart copy being inserted 3469 bp upstream in one introgressant (RZ1), showed significant up-regulation in both the leaf and root tissues (but more markedly in leaf) of all three introgressants though at variable degrees; (3) gene 3, to which a Dart copy being inserted 1467 bp downstream in one introgressant (RZ1), showed significant up-regulation in the leaf tissue of introgressants RZ2 and RZ35, and in the root tissue of all three introgressants at variable degrees; (4) gene 4, for which a Dart copy residing 2062 bp upstream being excised from all three introgressants (RZ1, RZ2 and RZ35), showed significant upregulation in the leaf tissue of all three introgressants, and in the root tissue of introgressants RZ1 and RZ35 at variable degrees; (5) gene 5, to which a Dart copy being inserted into the $9^{\text {th }}$ exon in all three introgressants (RZ1, RZ2 and RZ35), showed significant up-regulation only in the root tissue of introgressant 35; (6) gene 6 , to which a Dart copy being inserted into the $2^{\text {nd }}$ intron in two introgressants (RZ1 and RZ2), showed significant up-regulation only in the root tissue of introgressant 35. Albeit the dramatic changes (predominantly up-regulation) in transcription of all six studied genes in the introgressants relative to in the rice parental line, we noted that the changes were not associated with the presence or absence of the newly transposed Dart-related TEs under normal growing conditions.

We further investigated possible alteration in expression patterns of these six genes between the introgressants and their rice parental line under three kinds of abiotic stress conditions, salinity, alkaline, heavy metal ( $\mathrm{CuSO} 4$ and $\mathrm{HgCl} 2)$ and cold, which have been widely studied in rice [31]. We also included 5-azacytidine (5AC) treatment to test for possible relevance of alteration in gene expression to changes in cytosine methylation of these genes. A general conclusion we were able to formulate based on the results was that four of the six genes (1 to 4) showed sharply differential response, both with regard to the kinds of treatments and to the extent of response, to each of the abiotic stresses as well as to $5-\mathrm{AC}$ in the introgressants relative to their rice parental line in both tissues, but the rest two genes (5 and 6) showed grossly similar trend of responses to the treatments between the introgressants and their rice parental line in both tissues (Figure 6). For example, for gene1, significant alteration in its expression was detected only in one (CuSO4-upregulation) of the stress treatments in the leaf tissue and two treatments (alkaline-down-regulation and cold-up-regulation) in the root tissue, and 5AC did not exert an effect, in Matsumae; in contrast, in the introgressants, this gene was responsive to most or all the stress treatments and also to 5-AC, and being predominantly up-regulated (Figure 6). An opposite situation was observed for gene 2 in the leaf tissue in that four of the five stress treatments (except $\mathrm{CuSO} 4$ ) as well as 5-AC induced significant up-regulation of this gene in Matsumae; in contrast, two of the introgressants (RZ1 and RZ35) did not respond to any of the treatments at all, and one introgressant (RZ2) responded to four of the five stress treatments and to 5-AC, but all responses were of lower extents (though the same trend, i.e., upregulation) relative to those in Matsumae (Figure 6). Gene 3 and gene 4 also exhibited sharply differential responses to at least some of the treatments between Matsumae and the introgressants for each of the tissues. Thus, a general conclusion for the first four genes ( 1 to 4) was that, in spite of the sharp difference between the introgressants and their rice parental line, they all represented up-regulation in response to the stresses and to 5-AC, probably because the basal expression level of these genes was relatively low in rice (Figure 6, genes 1 to 4), and which often belonged to genes with intrinsic methylation modifications [32]. In contrast, the rest two genes (5 and 6 ) showed relatively smaller difference between the introgressants and their rice parental line, and all were predominantly down-regulated in response to the stress treatments, and either no change or also down-regulation in response to 5-AC treatments, probably because the basal expression level of these two genes was relatively high in rice, and hence they were probably belong to intrinsically unmethylated genes [32]. Taken the data of all six genes together, it could be concluded that, similar to the situation of under normal growing condition, the expression patterns of theses genes in the introgressant(s) vs. their rice parental line under the various stress conditions and 5-AC treatment, though were substantially different, were again not coupled with the presence or absence of the newly mobilized Dart-related TEs. However, the fact that at least in one of the studied rice lines, expression of each of the four genes ( 1 to 4 ) was up-regulated by 5 -AC treatment (Figure 6) suggests that these genes are likely relevant to cytosine methylation modification; the differential response to 5-AC among the lines might be due to their variable methylation patterns of these genes. 


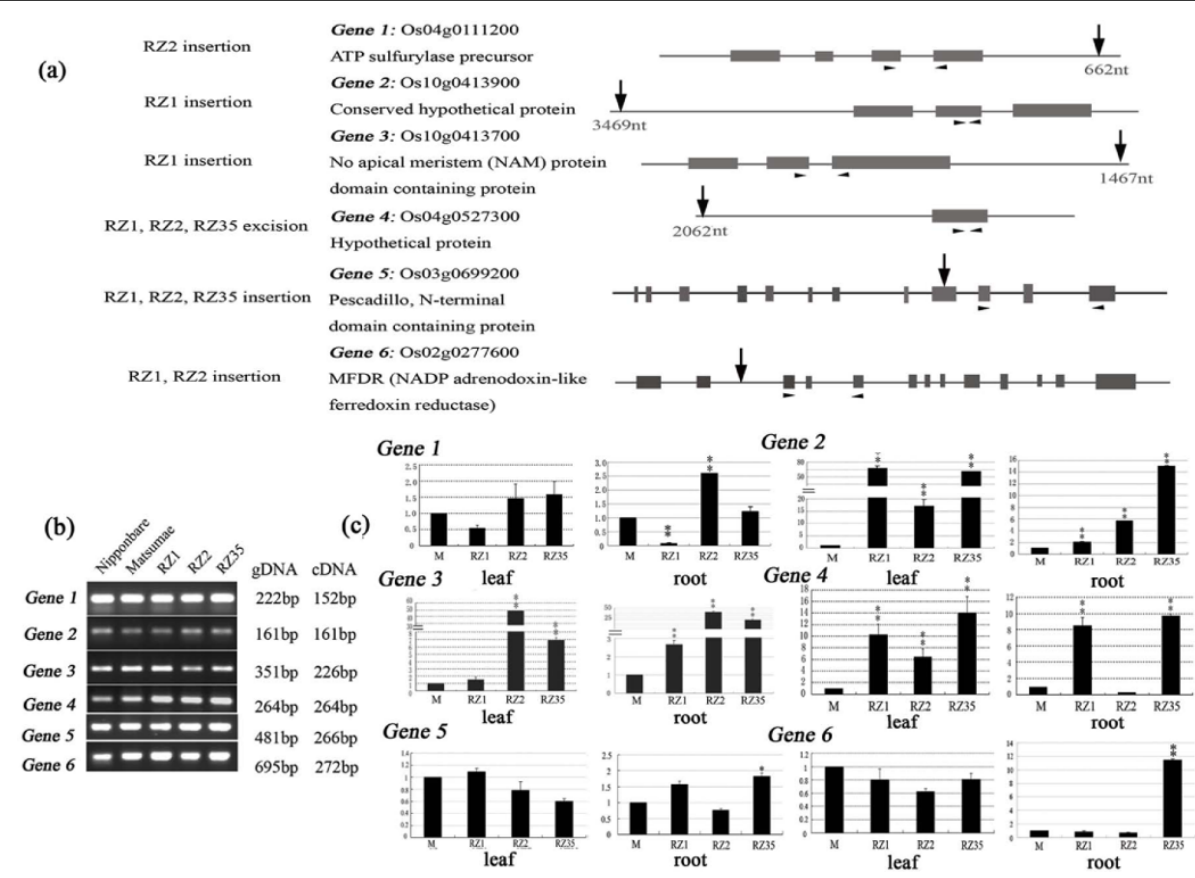

Figure 5 Measurement of expression of six genes adjacent to the newly excised or inserted Dart-related TEs in two tissues (leaf and root) taken from the three rice-Zizania introgressant(s) and their rice parental line Matsumae under normal growing condition by real-time qRT-PCR analysis. (a) Diagrams showing the excision or insertion positions (vertical arrows) of Dart-related TEs in each of the four genes, and positions (horizontal arrowheads) of the gene-specific primers. The grey rectangles denote exons for each gene. (b) Amplification of the six genes on genomic DNA as templates (20 ng each sample) from the introgressants and their rice parental line Matsumae. The standard cultivar Nipponbare was also included as an additional control. The near identical amplifications indicate lack of amplification bias by the designed primers. (c) Transcriptional expression of each of the six genes in the leaf and root tissues taken from the introgressants and their rice parental line, measured by real-time qRT-PCR. The relative abundance of transcripts (mean \pm SD) for each of the studied genes was calculated upon normalization against a rice $\beta$-actin gene (Genbank accession X79378). * and ** denote statistical significance at the 0.05 and 0.01 levels, respectively.

\section{Discussion}

Hybridization is prevalent in plants, which plays important roles in genome evolution, and may lead to speciation at both the homoploid level and followed by genome doubling (allopolyploid) [6,7,33-37]. Apart from direct transfer and recombinatory generation of genetic variations by hybridization, de novo genetic and epigenetic instabilities can be induced by the process per se, including transcriptional activation and mobilization of cryptic transposable elements (TEs) [15,16,29,38-42]. Several lines of circumstantial evidence have indicated that introgression of DNA or chromatin fragments from an alien species into a recipient genome may also produce similar effects in causing genetic and epigenetic instabilities and generate novel phenotypes $[11,17]$. We have reported previously that introgressive hybridization between rice (Oryza sativa) and Z. latifolia had induced rampant mobilization of two TEs, a copia-like LTR retrotransposon Tos 17 and a MITE mPing [21,43]. In this study, we extended the earlier findings and found that the Dart-related TEs were also transpositionally reactivated in the introgressants, although the elements were totally quiescent in the parental rice cultivar Matsumae. We validated the excisions and insertions by transposon-display (TEs) and sequencing, which ruled out genomic rearrangements as the major cause for the dramatically altered hybridization patterns detected by Southern blotting in the introgressants.

Although numerous studies have established correlative or causal links between TE activation and alteration in the element's cytosine methylation state $[26,27,30,44,45]$, we found that the Dart-related TEs were similarly hypermethylated along their entire length in the introgressants and their rice parental line Matsumae. Nonetheless, moderate alteration in the methylation patterns was discernible in the introgressants. Furthermore, given that the introgressants were at the $9^{\text {th }}$-selfed generation and stabilized in both phenotype and DNA fingerprinting patterns [20], we could not rule out the possibility that in earlier generations of the introgressants (no longer available for study), more marked methylation remodelling might have occurred in the Dart-related TEs, which however were either largely reverted to the original pattern and/or those individuals 


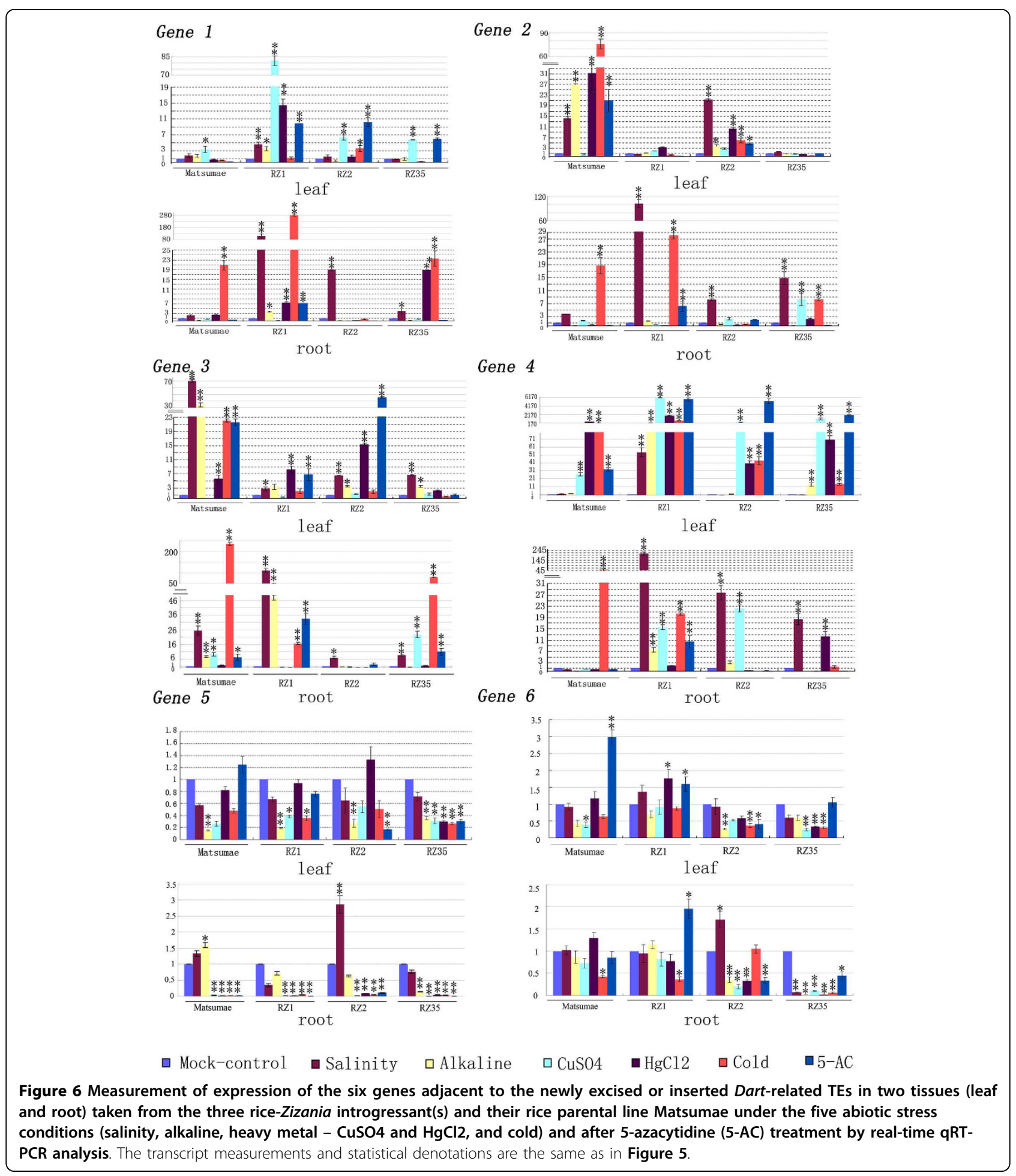

with more drastically altered patterns had been purged out during the sexual reproduction, probably due to reduced fitness. Therefore, it remains a formal possibility that alteration in cytosine methylation had been associated with mobility of the Dart-related TEs in the introgressants, a scenario gaining increased empirical support in a vast range of TEs and organisms [9-11,26,28,30,46].

An array of studies in both plants and animals has established that activity of TEs, particularly LTR 
retrotransposons, may significantly impact expression and function of their adjacent genes $[38,41]$. Nonetheless, other studies have indicated that the majority of newly transposed TEs particularly those with small-sizes like MITEs tended to insert into functionally neutral genomic regions and impose minor effects on their adjacent genes [31]. We found in this study that the six single-copy protein-coding genes adjacent to the newly excised or inserted Dart-related TEs exhibited significantly altered expression in the introgressants relative to their rice parental line under both normal and several abiotic-stress conditions. However, the altered gene expression in the introgressants was not coupled with the TE excisions or insertions, suggesting that other regulatory mechanisms were responsible for the altered gene expression in the introgressants. Because unbiased amplifications between the introgressants and their rice parental line were observed when their genomic DNA was used as templates, it is likely that epigenetic regulation was involved. The observation that for most of the genes, these rice lines exhibited sharply differential response to 5-AC treatment corroborated this possibility, which also accords with our previous results showing that substantial re-patterning of cytosine methylation occurred in the introgressants for amny genomic loci [47]. Further study is required to elucidate the exact molecular basis underlying the dramatically altered gene expression and their phenotypic consequence in these novel rice lines as a result of introgressive hybridization.

\section{Conclusion}

Results of this study have extended our previous findings by documenting that introgressive hybridization between rice and $Z$. latifolia has induced transpositional reactivation of another distinct family of cryptic TEs in the parental rice genome, namely, the Dart-related TEs, suggesting that introgression of chromatin from a realted alien species might have caused a general breakdown of the host cellular machinery responsible for repressive control of TE activity. Transposition of the Dart-related TEs was accompanied with a moderate alteration in the element's cytosine methylation in the introgressants. In addition, results of this study showed that extensive alteration in expression of a set of Dartadjacent, protein-coding genes occurred in the introgressants relative to their rice parental line, under both normal and various abiotic stress conditions. Nonetheless, the alteration in gene expression was not coupled with excision or insertion of the Dart-related TEs, implicating other regulatory mechanism(s) was underpinning the changes in gene expression in these novel rice introgressants.

\section{Methods}

\section{Plant lines}

Three introgression lines (RZ1, RZ2 and RZ35) derived from a cross between rice (cv. Matsumae) and Zizania latifolia Griseb, were used in this study [21]. The three stabilized introgressants (at the $9^{\text {th }}$ selfed generation) were homogeneous in phenotype and DNA fingerprinting patterns, and exhibited heritable, novel morphological characteristics in multiple traits compared with their rice parental cultivar Matsumae [20,21]. The introgressants were maintained along with their rice parental line (cv. Matsumae) by strict selfing in our laboratory.

\section{Abiotic stress and 5-azacytidine treatments}

Healthy and uniform seeds of three rice-Zizania introgressants (RZ1, RZ2 and RZ35) and their rice parental line cv. Matsumae were disinfected and thoroughly rinsed, and placed on petri-dishes covered with half-strength Murashige and Skoog (MS) medium in darkness at $25^{\circ} \mathrm{C}$. For the three kinds of abiotic stress treatments, seedlings were grown to the 3-leaf-stage, and then aqueous solutions respectively containing $5 \mathrm{mM} \mathrm{CuSO}_{4}$ (heavy metal), $5 \mathrm{mM} \mathrm{HgCl}_{2}$ (heavy metal), $10 \mathrm{mM} \mathrm{NaCl}$ (salinity) and $10 \mathrm{mM} \mathrm{NaHCO} 3$ (alkaline) containing the half-strength MS medium were added, and grown for one more week. For cold stress, the 3-leaf-stage seedlings were grown in the medium at $12^{\circ} \mathrm{C}$ for one week. The 5 -azacytidine (5-AC) treatment was conducted by treating the germinating seeds in the medium containing $50 \mathrm{mM} 5$-azacytidine (Sigma) for one week and then thoroughly rinsed with $\mathrm{ddH}_{2} \mathrm{O}$ and allowed the seedlings to grow in the medium up to the same stage as the other treatments. In all cases mockcontrol seedlings grown in the half-strength MS medium alone was included.

\section{Southern blot analysis}

Genomic DNA was isolated from leaf tissue of young seedlings at the same developmental stage from the various treatments and mock of the three rice-Zizania introgressants (RZ1, RZ2 and RZ35) and their rice parental line Matsumae by a modified CTAB method. To assess possible genetic changes in the patterns of the Dart-related TEs, the genomic DNA ( $3 \mu \mathrm{g}$, per lane) of each line (the mock-control) was digested by HindIII. To test for possible alteration in cytosine methylation of the Dart-related TEs, the genomic DNA of each line (the mock-control) was first digested with $\mathrm{BamHI}$ (to delineate the Dart-related TEs into three regions, 5'-, 3'-, and body-regions; see Results), followed by a second round of digestion with a pair of isoschizomers, HpaII and MspI, that recognize the same sequence 5'-CCGG but with differential sensitivity to methylation of the 
two cytosine residues. Digested DNA were run on $1 \%$ agarose gel and transferred onto Hybond $\mathrm{N}+$ nylon membrane (RPN 303B, Amersham-Pharmacia Biotech, Piscataway, New Jersey) by the alkaline transfer method recommended by the manufacturer.

In total, three pairs of primers specific respectively to the 5'-, 3'- and the body-region of the Dart-related TEs were designed to amplify the fragments to be used as hybridization probes. The primers are: (1) for the 5'region of Dart-related TEs: Dart5'-forward: 5'- aaatagggcatgaacccagc, Dart5'-reverse: 5'-ggtcgaaatcacccaaggtg; (2) for the 3'-region of Dart-related TEs: Dart3'-forward: 5'-tccagaccaaccccagtagaa, Dart3'-reverse: 5'-aaaaaaagcaaaggaaatgtataagg; (3) for the body-region of Dartrelated TEs: Dart-body-forward: 5'-ctagagaggattatcttagcgtagttgtt, Dart-body-reverse: 5'-cttcttcttacctgtagtggggatag. Authenticity of the amplified fragments was verified by sequencing. The fragments were then agarose gel-purified and labelled with fluorescein-11-dUTP by the Gene Images random prime-labelling module (AmershamPharmacia Biotech). Hybridizations were done with the Gene Images CDP-Star detection module (AmershamPharmacia Biotech). After washing twice with $0.2 \times \mathrm{SSC}$, $0.1 \% \mathrm{SDS}$ for $50 \mathrm{~min}$. The filters were exposed to X-ray films for chemiluminescence signal detection.

\section{Transposon display (TD), locus-specific PCR amplification and sequencing}

The genomic DNA (approximately 300 ng per sample) was cut with MseI and subject to transposons display (TD) following the protocol essentially as reported [48]. Three consecutively nested, sequence-specific primers targeting to the 3' end of Dart-related TEs were designed. Two specific primers (TDPrm1/TDPrm2 and $\mathrm{Mse}+\mathrm{C} / \mathrm{G}$ ) were respectively combined with the selective-amplification primers targeting the adapters, while the most external primer $(\mathrm{TIR}+\mathrm{N} / M s e \mathrm{I}+3)$ was used for further validation of the isolated TD bands. Detailed information concerning adapters and primers are listed in Additional files 1. The PCR amplification conditions and TD amplification products were resolved by PAGE and visualized by silver-staining [20]. Only clear and reproducible variant bands between two technical replications were considered as putative new insertions by the Dart-related TEs, and recovered for sequencing.

Based on the sequencing results by identifying the expected 3'-terminus of the Dart-related TEs, the contiguous flanking regions were extracted and used to query the Nipponbare genome sequence http://rgp.dna. affrc.go.jp by BlastN, and a set of locus-specific primers each being downstream of the Dart but compatible with the Dart-specific TD primers were designed with Primer 3 http://biocore.unl.edu/cgi-bin/primer3/primer3_www. cgi and those produced the expected results were listed in Tables 1 and 2. Each of these primers were then sequentially combined with the nested Dart-specific TD primers to reproduce the putative excisions and insertions identified by TD in the introgressant(s), and the amplicons were then sequenced for validation.

\section{RNA isolation and quantitative real-time-reverse transcriptase (RT)-PCR analysis}

Total RNA was isolated from the same young leaf tissue as used for DNA isolation and also from the root tissue of the same seedlings of the various treated and mock lines, with the Trizol Reagent (Invitrogen) according to the manufacturer's protocol. The RNA was then treated with DNaseI (Invitrogen) to eliminate possible genomic DNA contamination before being reverse transcribed with the SuperScript RNase H- Reverse Transcriptase (Invitrogen).

The expression of genes adjacent to the newly excised or inserted Dart-related TEs in the introgressant(s) was studied by quantitative real-time-RT-PCR using genespecific primers (see Additional file 2). The q-RT-PCR experiments were performed using a Roche LightCycler480 apparatus (Roche Inc.) according to the manufacturer's instruction and SYBR Premix Ex Taq (TOYOBO) as a DNA-specific fluorescent dye. The primers for the six studied genes were designed by the Primer 5 software (see Additional file 2). Expression of a rice $\beta$-actin gene (Genbank accession X79378) was used as internal control with the primer pairs 5'-atgccattctccgtctt and 5'-gctcctgctcgtagtc. The choice of the $\beta$-actin gene as the internal control was based on previous investigation showing that expression of this house-keeping gene between the tissues and under the various stress conditions was constant [49]. Conditions of q-RT-PCR were as reported [50].

\section{Additional material}

Additional file 1: Primers used in the transposon-display (TD) assay.

Additional file 2: Gene-specific primers used in expression analysis by real-time qRT-PCR

\section{Acknowledgements}

This study was supported by the State Key Basic Research and Development Plan of China (2005CB120805), and the Programme for Introducing Talents to Universities (B07017). We are grateful to two anonymous referees for constructive comments to improve the manuscript.

\section{Author details}

${ }^{1}$ Key Laboratory of Molecular Epigenetics of MOE and Institute of Genetics \& Cytology, Northeast Normal University, Changchun 130024, China. ${ }^{2}$ Faculty of Life Science, Liaoning University, Shenyang 110036, China.

\section{Authors' contributions}

NW carried out major parts of the experiments, analyzed the data and drafted the manuscript. HW, HW, DZ, CL, YW, XO and ZD participated in all 
the experiments. BL designed the work and finalized the manuscript. All authors read and approved the final manuscript.

Received: 18 March 2010 Accepted: 26 August 2010

Published: 26 August 2010

\section{References}

1. Shaked H, Kashkush K, Ozkan H, Feldman M, Levy AA: Sequence elimination and cytosine methylation are rapid and reproducible responses of the genome to wide hybridization and allopolyploidy in wheat. Plant Cell 2001, 13(8):1749-1759.

2. Ozkan H, Levy AA, Feldman M: Allopolyploidy-induced rapid genome evolution in the wheat (Aegilops-Triticum) group. Plant Cell 2001, 13(8):1735-1747.

3. Madlung A, Masuelli RW, Watson B, Reynolds SH, Davison J, Comai L: Remodeling of DNA methylation and phenotypic and transcriptional changes in synthetic Arabidopsis allotetraploids. Plant Physiol 2002, 129(2):733-746.

4. Salmon A, Ainouche ML, Wendel JF: Genetic and epigenetic consequences of recent hybridization and polyploidy in Spartina (Poaceae). Mol Ecol 2005, 14(4):1163-1175.

5. Gaeta RT, Pires JC, Iniguez-Luy F, Leon E, Osborn TC: Genomic changes in resynthesized Brassica napus and their effect on gene expression and phenotype. Plant Cell 2007, 19(11):3403-3417.

6. Chen ZJ: Genetic and epigenetic mechanisms for gene expression and phenotypic variation in plant polyploids. Annu Rev Plant Biol 2007 58:377-406.

7. Brennan AC, Bridle JR, Wang AL, Hiscock SJ, Abbott RJ: Adaptation and selection in the Senecio (Asteraceae) hybrid zone on Mount Etna, Sicily. New Phytol 2009, 183(3):702-717.

8. McClintock B: The significance of responses of the genome to challenge. Science 1984, 226(4676):792-801.

9. Comai L, Madlung A, Josefsson C, Tyagi A: Do the different parental 'heteromes' cause genomic shock in newly formed allopolyploids? Philos Trans R Soc Lond B Biol Sci 2003, 358(1434):1149-1155.

10. Michalak P: Epigenetic, transposon and small RNA determinants of hybrid dysfunctions. Heredity 2009, 102(1):45-50.

11. JA S: Mobile DNA and evolution in the 21st Century. Mobile DNA 2010, $1: 4$

12. Capy P, Chakrani F, Lemeunier F, Hartl DL, David JR: Active mariner transposable elements are widespread in natural populations of Drosophila simulans. Proc Bio/ Sci 1990, 242(1303):57-60.

13. Wessler SR, Bureau TE, White SE: LTR-retrotransposons and MITEs: important players in the evolution of plant genomes. Curr Opin Genet Dev 1995, 5(6):814-821

14. Kidwell MG, Lisch DR: Hybrid genetics. Transposons unbound. Nature 1998, 393(6680):22-23

15. Ungerer MC, Strakosh SC, Zhen Y: Genome expansion in three hybrid sunflower species is associated with retrotransposon proliferation. Curr Biol 2006, 16(20):R872-873.

16. Ungerer MC, Strakosh SC, Stimpson KM: Proliferation of Ty3/gypsy-like retrotransposons in hybrid sunflower taxa inferred from phylogenetic data. BMC Biol 2009, 7:40.

17. Remus R, Kammer C, Heller H, Schmitz B, Schell G, Doerfler W: Insertion of foreign DNA into an established mammalian genome can alter the methylation of cellular DNA sequences. J Virol 1999, 73(2):1010-1022.

18. Muller $\mathrm{K}$, Heller $\mathrm{H}$, Doerfler W: Foreign DNA integration. Genome-wide perturbations of methylation and transcription in the recipient genomes. J Biol Chem 2001, 276(17):14271-14278.

19. Liu Z, Wang Y, Shen Y, Guo W, Hao S, Liu B: Extensive alterations in DNA methylation and transcription in rice caused by introgression from Zizania latifolia. Plant Mol Biol 2004, 54(4):571-582

20. Wang YM, Dong ZY, Zhang ZJ, Lin XY, Shen Y, Zhou D, Liu B: Extensive de Novo genomic variation in rice induced by introgression from wild rice (Zizania latifolia Griseb.). Genetics 2005, 170(4):1945-1956.

21. Shan X, Liu Z, Dong Z, Wang Y, Chen Y, Lin X, Long L, Han F, Dong Y, Liu B: Mobilization of the active MITE transposons mPing and Pong in rice by introgression from wild rice (Zizania latifolia Griseb.). Mol Biol Evol 2005, 22(4):976-990.
22. Tsukahara S, Kobayashi A, Kawabe A, Mathieu O, Miura A, Kakutani T: Bursts of retrotransposition reproduced in Arabidopsis. Nature 2009, 461(7262):423-426.

23. Fujino $\mathrm{K}$, Sekiguchi $\mathrm{H}$, Kiguchi $\mathrm{T}$ : Identification of an active transposon in intact rice plants. Mol Genet Genomics 2005, 273(2):150-157.

24. Fujino $K$, Matsuda $Y$, Sekiguchi $H$ : Transcriptional activity of rice autonomous transposable element Dart. J Plant Physiol 2009, 166(14):1537-1543

25. Tsugane K, Maekawa M, Takagi K, Takahara H, Qian Q, Eun CH, lida S: An active DNA transposon $n$ Dart causing leaf variegation and mutable dwarfism and its related elements in rice. Plant J 2006, 45(1):46-57.

26. Fujino $\mathrm{K}$, Sekiguchi $\mathrm{H}$ : Site specific cytosine methylation in rice nonautonomous transposable element nDart. Plant Mol Biol 2008, 67(5):511-518.

27. Grandbastien MA: Stress activation and genomic impact of plant retrotransposons. J Soc Biol 2004, 198(4):425-432.

28. O'Neill RJ, O'Neill MJ, Graves JA: Undermethylation associated with retroelement activation and chromosome remodelling in an interspecific mammalian hybrid. Nature 1998, 393(6680):68-72.

29. Kawakami T, Strakosh SC, Zhen Y, Ungerer MC: Different scales of Ty1/ copia-like retrotransposon proliferation in the genomes of three diploid hybrid sunflower species. Heredity 2010, 104:341-350.

30. Lisch D: Epigenetic regulation of transposable elements in plants. Annu Rev Plant Biol 2009, 60:43-66.

31. Naito K, Zhang F, Tsukiyama T, Saito H, Hancock CN, Richardson AO, Okumoto $Y$, Tanisaka T, Wessler SR: Unexpected consequences of a sudden and massive transposon amplification on rice gene expression. Nature 2009, 461(7267):1130-1134.

32. Zhang $X$, Yazaki J, Sundaresan A, Cokus S, Chan SW, Chen H, Henderson IR, Shinn $P$, Pellegrini $M$, Jacobsen SE, et al: Genome-wide high-resolution mapping and functional analysis of DNA methylation in arabidopsis. Cell 2006, 126(6):1189-1201.

33. Stebbins GL: The synthetic approach to problems of organic evolution. Cold Spring Harb Symp Quant Biol 1959, 24:305-311.

34. Arnold N, Seibl R, Kessler C, Wienberg J: Nonradioactive in situ hybridization with digoxigenin labeled DNA probes. Biotech Histochem 1992, 67(2):59-67.

35. Rieseberg LH, Raymond O, Rosenthal DM, Lai Z, Livingstone K, Nakazato T, Durphy JL, Schwarzbach AE, Donovan LA, Lexer C: Major ecological transitions in wild sunflowers facilitated by hybridization. Science 2003, 301(5637):1211-1216.

36. Adams $\mathrm{KL}$, Wendel JF: Polyploidy and genome evolution in plants. Curr Opin Plant Biol 2005, 8(2):135-141.

37. Soltis PS, Soltis DE: The role of hybridization in plant speciation. Annu Rev Plant Biol 2009, 60:561-588.

38. Kashkush K, Feldman M, Levy AA: Transcriptional activation of retrotransposons alters the expression of adjacent genes in wheat. Nat Genet 2003, 33(1):102-106.

39. Michalak P, Noor MA: Genome-wide patterns of expression in Drosophila pure species and hybrid males. Mol Biol Evol 2003, 20(7):1070-1076.

40. Wang J, Tian L, Lee HS, Wei NE, Jiang H, Watson B, Madlung A, Osborn TC, Doerge RW, Comai $L$, et al: Genomewide nonadditive gene regulation in Arabidopsis allotetraploids. Genetics 2006, 172(1):507-517.

41. Kashkush K, Khasdan V: Large-scale survey of cytosine methylation of retrotransposons and the impact of readout transcription from long terminal repeats on expression of adjacent rice genes. Genetics 2007 , 177(4):1975-1985.

42. Hegarty MJ, Barker GL, Brennan AC, Edwards KJ, Abbott RJ, Hiscock SJ: Extreme changes to gene expression associated with homoploid hybrid speciation. Mol Ecol 2009, 18(5):877-889.

43. Liu B, Wendel JF: Retrotransposon activation followed by rapid repression in introgressed rice plants. Genome 2000, 43(5):874-880

44. Kato M, Miura A, Bender J, Jacobsen SE, Kakutani T: Role of CG and nonCG methylation in immobilization of transposons in Arabidopsis. Curr Biol 2003, 13(5):421-426.

45. Huang J, Zhang K, Shen Y, Huang Z, Li M, Tang D, Gu M, Cheng Z: Identification of a high frequency transposon induced by tissue culture, nDaiZ, a member of the hAT family in rice. Genomics 2009, 93(3):274-281. 
46. O'Donnell KA, Boeke JD: Mighty Piwis defend the germline against genome intruders. Cell 2007, 129(1):37-44.

47. Liu B, Zhang S, Zhu X, Yang Q, Wu S, Mei M, Mauleon R, Leach J, Mew T, Leung $\mathrm{H}$ : Candidate defense genes as predictors of quantitative blast resistance in rice. Mol Plant Microbe Interact 2004, 17(10):1146-1152.

48. Schulman AH, Flavell AJ, Ellis TH: The application of LTR retrotransposons as molecular markers in plants. Methods Mol Biol 2004, 260:145-173.

49. Caldana C, Scheible WR, Mueller-Roeber B, Ruzicic S: A quantitative RT-PCR platform for high-throughput expression profiling of 2500 rice transcription factors. Plant Methods 2007, 3:7.

50. Wang H, Chai Y, Chu X, Zhao Y, Wu Y, Zhao J, Ngezahayo F, Xu C, Liu B: Molecular characterization of a rice mutator-phenotype derived from an incompatible cross-pollination reveals transgenerational mobilization of multiple transposable elements and extensive epigenetic instability. BMC Plant Biol 2009, 9:63.

doi:10.1186/1471-2229-10-190

Cite this article as: Wang et al: Transpositional reactivation of the Dart transposon family in rice lines derived from introgressive hybridization with Zizania latifolia. BMC Plant Biology 2010 10:190.

\section{Submit your next manuscript to BioMed Central} and take full advantage of:

- Convenient online submission

- Thorough peer review

- No space constraints or color figure charges

- Immediate publication on acceptance

- Inclusion in PubMed, CAS, Scopus and Google Scholar

- Research which is freely available for redistribution

Submit your manuscript at www.biomedcentral.com/submit 